\title{
Investment, financial markets and uncertainty *
}

\author{
Philip Arestis ${ }^{* *}$ \\ Ana Rosa González-Martinez **** \\ Óscar Dejuán
}

\begin{abstract}
This contribution provides a theoretical explanation of the accumulation process, which focuses on the presence of correlations between physical and financial investment, and how the latter could affect the former. It also accounts for the influence of the cost of external finance and the impact of financial uncertainty as proxied by the interest rate and the exchange rate respectively; thereby utilising the Keynesian notion of conventions in the determination of investment. Our model is estimated by applying the difference GMM and the system GMM to a panel of 14 OECD countries from 1970 to 2010 .
\end{abstract}

Keywords: Accumulation; Financial markets; Conventions; Uncertainty; Keynesian economics.

\section{Resumo}

Investimento, mercados financeiros e incerteza

Esta contribuição fornece uma explicação teórica do processo de acumulação, enfatizando a presença de correlações entre os investimentos produtivo e financeiro e, sobretudo, como este último pode afetar o primeiro. Também se considera a influência do custo do financiamento externo e do impacto da incerteza financeira, tomando como proxies, respectivamente, a taxa de juros e a taxa de câmbio. Ou seja, utiliza-se a noção keynesiana de convenções na determinação do investimento. O modelo é estimado a partir da aplicação de modelo GMM num painel de 14 países da OCDE de 1970 a 2010.

Palavras-chave: Acumulação; Mercados financeiros; Convenções; Incerteza; Economia keynesiana. JEL B22, C23, E22.

\section{Introduction}

The development of the financial sector since the financial liberalisation process, which started in the early 1970s, and the great evolution of financial investment during this period, suggests that serious consideration of this complex phenomenon is in order. This should enable one to extend the Keynesian investment function, which does not fully account for the links between financial elements and the real economy. In this context we may note that over the period since the beginning of financial liberalisation in the early 1970s, the majority of the OECD countries have experienced an increase in their profit shares, at the same time as a slowing down of the rhythm of accumulation of physical assets. Both

\footnotetext{
* Artigo recebido em 20 de novembro de 2016 e aprovado em 25 de novembro de 2016.

** University of Cambridge, Reino Unido. E-mail: pa267@ cam.ac.uk.

*** Social and Regional Economics, Rotterdam, The Netherlands. E-mail: ar.gonzm@gmail.com.

***** University of Castilla-La Mancha, Espanha. E-mail: oscar.dejuan@uclm.es.
} 
phenomena show a controversial relationship, since from a theoretical point of view, the higher profit shares could be interpreted as an increase in the amount of internal resources available for investment. However, this higher amount of internal funds has not promoted the expected acceleration of the path of capital accumulation.

At first sight, this could demonstrate the extent of financial investment crowding out physical investment (Stockhammer, 2004a). It is thereby crucial to study the inverse relationship between profits and capital accumulation, given that the conflict which emerges has important consequences for effective demand and long-run growth. Specifically, firms have to decide between two options: a) acquiring capital goods such as machinery, equipment and vehicles, which generate demand in the current period, and influence the production of the economy, thereby creating employment and wealth for future generations; or, b) promoting financial investment, which permits entrepreneurs to quickly obtain short-run speculative gains without worrying about the long-run.

The increasing importance of financial activities also exerts another effect on accumulation via uncertainty. The development of financial activities, which has permitted the appearance of new activities and financial assets without strong regulation, has boosted speculation, thereby promoting the creation of financial bubbles. According to this view, an increase in uncertainty means that businessmen face difficulties in their attempt to foresee the future, which is less predictable under these circumstances. The inclusion of uncertainty in our explanation of the accumulation process in capitalist mature economies enables the possibility to utilise the Keynesian notion of conventions, which helps businessmen in their investment decisions.

The theoretical proposition as postulated in this contribution subsequently undergoes an empirical investigation in a sample of 14 OECD economies over the period 1970-2010. We employ the difference GMM and the system GMM for this purpose, which permits us to account for the presence of common determinants in the postulated dynamic phenomenon and in the case of different open economies.

The remainder of this contribution is organized as follows. The foundations of the proposed investment function are presented in section 1. The testable hypothesis is clarified and discussed in sections 2 and 3. Section 4 deals with the econometric techniques employed for the purpose of the estimated relationships. In section 5 we describe the data utilised. The derived results are discussed in section 6. Finally, concluding remarks are provided.

\section{Investment with labour constraints}

We begin with the Kaleckian investment function with labour constraints, as presented by Ryoo and Skott (2008) and Skott and Zipperer (2011). This 
approach accounts for the effect of this constraint on the accumulation pace of mature economies (see, also, Skott, 1989, and Stockhammer, 2004b). It portrays the rate of accumulation, $g$ (which is equivalent to $I / K$, where $I$ is investment and $K$ capital stock), as a linear function of the capacity utilization, $u$, and the profit share, $\pi$, and the rate of employment, $e$, as shown in equation (1):

$$
g=I / K=\beta_{0}+\beta_{1} u+\beta_{2} \pi-\beta_{3} e
$$

where $u$ is measured by the output/capital ratio ${ }^{1}$.

Skott and Zipperer (2011) consider the relevance of employment as the main feature of mature economies in order to determine the rate of accumulation or the rate of saving. According to this view, increasing employment rates are perceived as a signal by firms for a need for higher profit shares in order to maintain their rate of accumulation. Specifically, high levels of employment promote conflict between workers and firms, and favour the former group, which at the end of the day depresses animal spirits. Moreover, the existence of this labour constraint could generate an indirect and negative effect on accumulation when the economy is closed to a full-employment position. This is so since contractionary economic policies could be implemented in order to slow down economic growth. However, at first sight the analysis of the empirical data questions this premise, given that increasing involuntary unemployment is a general trend that has been observed in the majority of European economies since 1960 (Nickell and Nunziata, 2002). In this sense, decreasing rates of employment could be understood by firms as a negative signal of the market, since they expect a reduction in future demand in view of the newly unemployed workers. Nevertheless, this negative impact does not take place due to the existence of hysteresis in this market. This has allowed the development of a labour constraint in economies where the normal conditions of the labour market are far from full employment (DiNardo; Moore, 1999).

However, equation (1) ignores the role of the normal rate of capacity utilization, which is considered as exogenously determined in both formulations. From a Kaleckian standpoint (Amadeo, 1986; Dutt, 1997), this normal rate is considered as a key element in the investment decision, due to the fact that accumulation dynamics are driven by the gap between the current rate of capacity utilization and the normal one, which is an endogenous element. Excess capacity has an influence not only in the short run but also in the long run. According to this view, firms maintain idle capacity in normal conditions due to the presence of uncertainty, which compels them to have excess capacity to respond to unexpected increases in demand (Lavoie et al., 2004). An alternative explanation of the

(1) We may note that equation (1) is rooted in the model developed by Dutt (1984) and Bhaduri and Marglin (1990), and is based on the expression: $g=I / K=\beta_{0}+\beta_{1} u+\beta_{2} \pi$, where the symbols are as in equation (1). Further consideration of this function is provided in Dutt (2011). 
presence of deviations between the current capacity utilization rate and its normal level is provided by Dallery and van Treeck (2011), which introduces two different targets: desired capacity utilization, and desired profitability. In the context of the latter contribution, firms prefer to work in order to satisfy their objective of profitability instead of their capacity utilization target.

\section{The relevance of the real rate of interest and uncertainty to investment}

The investment model described in equation (1) needs to be widened by considering the impact of the real long-term interest rate, $i$, as other contributors suggest (Ryoo and Skott, 2008, Stockhammer and Grafl, 2010). Ceteris paribus, we can expect entrepreneurs to postpone their new investment projects under the presence of an increasing cost of external finance. However, if expectations about demand growth are powerful enough, demand and the rate of interest can move in parallel; and the final effect of the rate of interest on accumulation could be positive (Radcliffe Report, 1957) ${ }^{2}$. However, variations in the rate of interest must be considered, since they provoke an income redistribution process between rentiers and firms, which affects consumption and eventually accumulation. Keynes (1936) considers the long-term interest rate as a conventional phenomenon, in the sense that it is not determined entirely by the monetary authorities, but it also incorporates the expectations of the market about future monetary policy. According to this notion, there is room to emphasise businessmen's expectations about long-run interest rates, which permit the inclusion of their predictions about the cost of externally financing new investment projects. Instead of considering only the real long-term rate of interest and assuming the conventional level of this variable exogenously determined, our proposal includes the deviation of the real long-term interest rate from its conventional level. As a result, the accumulation relationship (1) can be written as in (2):

$$
g=I / K=\beta_{0}+\beta_{1} u+\beta_{2} \pi-\beta_{3} e-\beta_{4} d i
$$

where the symbols are as in (1) with the exception of $d i$, which stands for the deviation of the long-term real rate of interest from its conventional level ${ }^{3}$.

However, equation (2) must consider uncertainty. This is so since uncertainty influences accumulation given that investment frequently entails very specific capital goods, implying that sunk costs change. A depressing effect on accumulation also emerges in view of the possibility of postponing the decision to

(2) Hein and Ochsen (2003) provide evidence for the United States over the period 1983-95 that supports the proposition mentioned in the text. Although in this particular situation the effect of the rate of interest on accumulation could be positive, in general terms, the existence of an inverse relationship between these variables has been demonstrated by using the Kaldorian/Robinsonian framework (Lavoie, 1995; Hein, 2007).

(3) As suggested by Keynes (1936), the 'conventional' level of a variable is the value of a variable such the interest that has been prominent in the recent past and is expected to prevail in the near future. 
invest in order to search for better information, which would make the decisionmaking process easier. The presence of uncertainty has been emphasised in view of the financial crisis of August 2007, and particularly after some events such as the collapse of several investment banks in the United States and the development of housing bubbles in countries like Spain. This experience also highlights that agents are far from having rational expectations and probability cannot be considered as a proper way to forecast the evolution of the economic system. Investment is depressed by the presence of uncertainty, in view of the assumption of a nonergodic world, where there is no possibility of forecasting the future based on the past by using mathematical tools. According to this formulation, businessmen cannot predict profitability or expected demand and ignore what might modify the environment in which they have to take their decisions and invest (Davidson, 1991). Keynes (1936) introduced animal spirits, which prompt entrepreneurs to invest in the current period rather than wait and invest in the future ${ }^{4}$. However, this feature, which makes the notion of animal spirits attractive, is at the same time its Achilles' heel, in that they could be easily disappointed by the presence of uncertainty in the economy due to the fact that the animal spirits are based on subjective factors. The inclusion of uncertainty in the previous accumulation function produces equation (3):

$$
g=I / K=\beta_{0}+\beta_{1} u+\beta_{2} \pi-\beta_{3} e-\beta_{4} d i-\beta_{5} V
$$

where the variables are as before with the exception of $V$, which stands for uncertainty. We assume that $V$ can be approximated by the deviation between the real exchange rate and its conventional level.

\section{Investment in a financialised economy and expectations}

Regarding the studies which examine the impact of financialisation on accumulation, Hein (2007), Ryoo and Skott (2008) and Stockhammer (2004a) are the most important. These contributions share common theoretical explanations with the Bhaduri and Marglin (1990) investment function. However, there are differences between them regarding the way in which the financial elements are introduced. Stockhammer (2004a) proxies financialisation by the ratio of interest and dividend income to the value added of the non-financial business sector. Hein (2007) introduces the debt to capital ratio, while Ryoo and Skott (2008) compute the debt to capital and retained earnings to capital ratios. However, and as we argue below, our approach assumes investment as the relationship between physical investment and its two financial alternatives, namely bonds and equities. Clearly this is a different explanation from the one offered by the above mentioned studies. Moreover, our proposal also accounts for the incidence of uncertainty.

(4) Keynes (1936) relates animal spirits with whim, sentiment, digestion, nerves and hysteria of entrepreneurs. 
The starting point of our theoretical explanation is the investment function as in equation (3) above. However, we modify it in two ways. First, we include businessmen's expectations about the future development of the economy and the notion of conventions as the tool that businessmen use in their investmentdecisions to account for an uncertain world. Second, we adapt the model to two of the characteristic features of a financialised economy, i.e. a relevant financial market and alternative financial assets. These aspects are discussed in the following section.

\subsection{The role of expectations and conventions}

The investment decision has to be taken in a context characterised by the presence of uncertainty and the absence of perfect information. In this uncertain world there is no room to apply probability as the ultimate way to predict the expected values of economic variables (Davidson, 1991). However, subjective elements (animal spirits and expectations) occupy an exceptional position. Our contribution, in an attempt to overcome the impossibility of knowing the future, introduces businessmen's expectations that relate to several aspects. The latter are: a) aggregate demand, which is the engine of the model; b) capacity utilization, which is the most important indicator of the level of economic activity and provides the opportunity to model expectations about future demand; c) a proxy of financial uncertainty, which accounts for expectations about the exchange rate; and d) the stock market, whose development provides new kinds of business opportunities.

Our model assigns an important role to the acceleration principle, which accounts for expectations about future aggregate demand, $y$. These expectations are crucial in order to determine the effective demand of the economy, via investment, employment, and consumption. However, the presence of uncertainty prevents businessmen from precisely predicting expected demand, thus they can only approximate it by considering some stability in the current economic situation, as well as by considering current aggregate demand as a proxy of expected demand. In addition, and in terms of the specification of the investment function, we have to complete the role of expectations about demand by utilising the notion of the normal rate of capacity utilization. As a result, we include as another determinant of accumulation, the deviation between effective capacity utilization and its 'normal' rate, $d u$, since entrepreneurs normally desire some idle capacity in order to deal with unexpected increases in demand. Introducing these variables in equation (3), the investment function is summarised as in expression (4):

$$
g=\beta_{0}+\beta_{1} y+\beta_{2} d u+\beta_{3} \pi-\beta_{4} e-\beta_{5} d i-\beta_{6} V
$$


where the symbols are as in equation (3) with the exception of $y$, which stands for expected demand, and $d u$, which is the deviation of capacity utilization from its conventional level 5 .

Furthermore, our approach considers the exchange rate as a source of uncertainty and substitutes the generic variable $V$ by the deviation between the current exchange rate and its conventional level, $d r$. In economics, the power of expectations is strong, in the sense that in some cases expectations can be selffulfilling prophecies (Keynes, 1936). A common feature of capitalist economies is their openness to international trade, thus our model considers the real exchange rate as a proxy of uncertainty, since its impact is important not only for the financial markets but also for the goods market. However, the impact, which emanates from the exchange rate, could have an ambiguous effect on accumulation. By assuming negative expectations about the future value of the currency, i.e. businessmen expect losses in its value, there would be a negative effect on investment to the extent that they rely on imports of capital goods. The negative expectations about the future value of the currency could also depress accumulation indirectly via unfavourable expectations of inflation and future interest rates. However, at the same time, a falling exchange rate favours exports, which provides incentives to invest and sell goods on the international markets.

Accounting for deviations between the real exchange rate and its conventional level as a way to cope with uncertainty, the investment function becomes (5):

$$
g=\beta_{0}+\beta_{1} y+\beta_{2} d u+\beta_{3} \pi-\beta_{4} e-\beta_{5} d i-\beta_{6} d r e
$$

where the symbols are as before with the exception of dre, which stands for the deviation between the exchange rate and its conventional level.

\subsection{Introducing the financial sector}

The major development of finance in general over the period of our investigation requires special attention. This requirement is even more important in view of the failure of the New Consensus Macroeconomics, which ignores the role of money and financial markets where the presence of links between the real and the financial sectors of the economy is unquestionable (Arestis, 2009). Specifically, the growth of profits, which did not provoke an acceleration in the accumulation of physical assets, provides the rationale for investigating the possibility of a negative

(5) This deviation and those which appear through the text are defined as shown immediately below:

$$
d \kappa_{i, t-1}=\frac{\kappa_{i, t-1}-\kappa^{*}}{\kappa^{*}}
$$

where $\kappa$ is the effective rate of the variable (rate of capacity utilization in this particular case) and $\kappa^{*}$ is its normal or conventional rate (e.g. normal rate of capacity utilization). 
relationship between capital accumulation and its main financial alternatives; namely, equities and the US bonds. It needs to be noted that the latter has been traditionally considered as a non-risky asset. The development of the stock market is a clear signal that the role of 'equities' as an important financial asset should be seriously considered. This particular asset makes it possible to revise investors' long-run obligations in a short-run horizon. In this way, businessmen can rescue some of their invested funds when mistakes in their decisions are evident. It should be said, though, that the counterpart of this advantage is that the investment yields are unknown. We assume a negative impact of stock markets on accumulation in view of the presence of several financial crises in recent years (European crisis in 1992, Asian crisis in 1997, dot-com bubble in 2001, financial crisis in August 2007). This portrays the development of financial bubbles that result in a more uncertain and unstable economy. This kind of phenomena highlights the preference of capital flows for speculative and financial activities rather than for productive ones; the reason is of course that they permit rapid capital gains without involving obligations in the long-run ${ }^{6}$. This relevant and controversial role of the stock market is enhanced in the current globalized economy where, generally speaking, capital movements are enormous ${ }^{7}$. Keynes (1936) points to a positive effect of the stock market on accumulation, due to the fact that this market makes it possible to revise businessmen's commitments when their expectations about future profitability fail. Keynes (op. cit.) also suggests a negative relationship under the presence of financial bubbles where the role of animal spirits becomes stronger. In order to account for these possibilities, our proposed model includes a new explanatory variable, which is built as a deviation between the stock market index and its conventional level. The latter permits us to consider simultaneously the evolution of the stock market and businessmen's expectations about its development. The presence of expectations plays a key role in the majority of economic affairs, but this role is even stronger in the particular case of the stock market, where the decisions that are focused on the achievement of capital gains through speculation have to be taken rapidly and are not always based upon objective and mathematical elements of calculation (Keynes, 1936). The inclusion of this deviation emphasizes the role of expectations and allows one to take the long-run decision on investment, which is related to the evolution of the stock market over a long period of time.

Regarding the US-bond market, its relative and traditional safety consideration makes it interesting to include in our analysis. This would enable us

(6) This assumption differs from the relevant one of Brainard and Tobin $(1968,1977)$. The latter point to a positive relationship between both elements since the stock market is an alternative source of finance.

(7) In terms of gross domestic product (GDP) the volume of financial transactions is 70 times greater than the current world GDP while in the mid 1990s it was around 25 times (see Fundación Ideas, 2010). It is, thus, not surprising that the Tobin tax is under consideration to contain the enormous speculative capital flow movements (Tobin, 1978; Arestis; Sawyer, 1997; Brondolo, 2011). 
to consider the risk aversion of some entrepreneurs, and specifically, study the presence of the depressing effects of non-risky financial investments with known yields on risky physical investments. Despite the high volume of US public debt ${ }^{8}$, US bonds are safe for several reasons: a) the US public sector has never defaulted; b) the fiscal pressure of this economy is low, which permits the possibility of tax increases to finance its public deficit; ${ }^{9}$ and c) this high rate of public indebtedness is due to the expansionary policy after the crisis of August 2007.

In view of these arguments, we proceed to include the yield of the US Treasury long-term bonds in our investment equation, in order to analyse a possible relationship between physical investment, that is a commitment to the long-run with uncertain results, and this particular financial investment, whose yields are known when taking the investment decision. Our approach assumes a negative effect of the US bond yields on accumulation, due to businessmen's expectations that it is more attractive to invest some of their profits in public debt with a low risk than to start a new risky project with unknown yields.

Introducing the impact of stock markets and yields of US long-term bonds and retaining the assumed linear specification, our theoretical premise is captured as follows:

$$
g=\beta_{0}+\beta_{1} y+\beta_{2} d u+\beta_{3} \pi-\beta_{4} e-\beta_{5} d i-\beta_{6} d r e-\beta_{7} d S-\beta_{8} r b+\xi
$$

where $\beta_{i}$ are the coefficients which are to be estimated, with $\beta_{0}$ being the intercept; and $\xi$ as a random error term. All the variables are as in equation (5) with the exception of $d S$, which stands for the deviation of the stock market index from its conventional level, and $r b$, which is the US Treasury bond interest rate ${ }^{10}$.

\section{Econometric analysis}

We employ the panel data technique (Baltagi, 2006) for the following two reasons. First, we choose the panel data technique to account for the presence of common characteristics among the countries in our sample. This effect cannot be ignored due to the existence of correlations between the unobserved heterogeneity and the explanatory variables (Baltagi, 1995) ${ }^{11}$. Second, panel data analysis makes

(8) The International Monetary Fund estimates the volume of US public debt as $99.33 \%$ of GDP in 2011 (IMF, 2010).

(9) The tax to revenue ratio in the US in 2010 was $24.8 \%$, the third lowest in the OECD countries, while the average of the EU-27 was around $39.3 \%$ (OECD, 2011).

(10) The inclusion of expectations about the development of several variables, especially in the case of financial ones, is relevant due to the presence of uncertainty, which emerges from different sources. However, our proposal does not include a deviation of the US Treasury bond yields in order to account for uncertainty and expectations since this particular asset is not considered risky and volatile.

(11) In other words, this technique accounts for the effects, which provoke the same influence on each individual case in period $t$ (individual effects) and those effects, which differ from each individual case but are constant through the whole period (temporary effects). 
is possible to predict the behaviour of individuals more precisely than other techniques, since it studies particular individual cases and uses this information to make predictions. In other words, this method utilises acquired knowledge from past experience for prediction purposes (Hsiao and Mountain, 1994).

In order to test our theoretical propositions, two techniques are applied: the linear generalized method of moments (GMM), i.e. difference GMM, and the system GMM. The latter improves the results obtained with the former technique because the system GMM increases the efficiency of the estimators under additional conditions, i.e. the presence of persistence (autocorrelation and individual effects) through time (Alonso-Borrego and Arellano, 1996). The utilization of GMM is required, simply because traditional estimation procedures such as fixed effects estimation are inconsistent in dynamic panels. Following Baltagi (2006), this relationship shows how a variable in period $t$, say $y_{i t}$, could be explained through the value of the same variable in period $t-1, y_{i, t-1}$, along with other different explanatory elements, $x_{i t}^{\prime}$, and a random error term, $\eta_{i t}$. Equations (7) and (8) make the point. So, equation (7) is:

$$
y_{i t}=\delta y_{i, t-1}+x_{i t}^{\prime} \beta+\eta_{i t}
$$

where $\delta$ is a scalar, $x_{i t}^{\prime}$ is a $1 \times \mathrm{K}$ vector, and $\beta$ is $\mathrm{K} \times 1$ vector; $i=1, \ldots, N$ and $t=1$, $\ldots, T$, with equation (8) explaining the random error term, $\eta_{i t}$, which includes individual unobserved effects, $\mu_{i}$, and the genuine random error term, $\varepsilon_{i t}$

$$
\eta_{i t}=\mu_{i}+\varepsilon_{i t}
$$

where $\mu_{i}^{\sim} \operatorname{IID}\left(0, \sigma_{\mu}^{2}\right)$ and $\varepsilon_{i t} \sim \operatorname{IID}\left(0, \sigma_{\varepsilon}^{2}\right)$ are independent of each other and among themselves.

The difference GMM (Arellano and Bond, 1991) copes with autocorrelation problems by using as internal instruments lagged values of the levels of the variables, which appear on the right-hand side of equation (7). The way to work with instrumental variables is to find an instrument, which is not correlated with the first difference of the error term, but is correlated with the variable to be estimated. The basic idea of this kind of technique is to estimate the model by combining several instruments around a single vector of parameters, in order to obtain the minimum correlations between the error term and the relevant instruments. In particular, this technique considers as suitable instruments the second- and higher-order lags of the regressors in the event of no serial correlation in the time-varying component of the disturbance term. This method also considers the first difference of both sides of the initial equation, which permits the 
elimination of country-specific effects. ${ }^{12}$ The first step of this technique is as in equation (9):

$$
y_{i t}-y_{i, t-1}=\delta\left(y_{i, t-1}-y_{i, t-2}\right)+\left(x_{i t}-x_{i, t-1}\right)^{\prime} \beta+\left(\eta_{i t}-\eta_{i, t-1}\right)
$$

where $\left(\eta_{i t}-\eta_{i, t-1}\right)$ is a first order moving average model MA(1) with a unit root, which is described according to equation (10):

$$
y_{t}=\mu+\eta_{t}+\psi_{1} \eta_{t-1}
$$

where $\psi_{1}$ is the estimated coefficient, $E\left(y_{t}\right)=\mu$ and $\eta_{t}$ is a random variable with $E\left(\eta_{t}\right)=0$ and $\operatorname{Var}\left(\eta_{t}\right)=\sigma^{2}$.

The presence of endogeneity amongst the explanatory variables and the existence of correlation between the error term and the lagged dependent variable require the application of instrumental variables. Specifically, the moment conditions, which are used by difference GMM are shown in equations (11) and (12):

$$
\begin{aligned}
& E\left[y_{i, t-s}\left(\eta_{i t}-\eta_{i, t-1}\right)\right]=0 \\
& E\left[x_{i, t-s}\left(\eta_{i t}-\eta_{i, t-1}\right)\right]=0
\end{aligned}
$$

for $s \geq 2 ; t=1, \ldots, T$

Under the presence of autocorrelation and individual effects through time, lagged values would not be adequate instruments for the model in differences. In order to account for this problem, and improve the efficiency of the GMM estimators, Arellano and Bover (1995) and Blundell and Bond (1998) have developed the system GMM, which computes the equation in differences, as shown in (9), and also adds an equation in levels as shown in equation (13):

$$
y_{i t}=\alpha_{i}+\delta y_{i, t-1}+x_{i t}^{\prime} \beta+\eta_{i t}
$$

where $\alpha_{i}$ captures fixed effects. The equation in levels considers the lagged differences of the regressors as instruments, while the regression in differences utilises the same instruments as in the difference GMM technique. Equation (13) shows how $y_{i t}$ is a function of $\alpha_{i}$, and it is correlated with the compound error, $\eta_{i t}$. The presence of country-specific effects disappears by first-differencing, but is kept in the equation in levels. The instruments for the regression in differences are those which are used in the difference GMM estimator. In the case of the equation in levels, the relevant instruments are the lagged differences of the variables. The system GMM utilises the equation in levels and tries to find instruments, which are

(12) In our case these particular effects for each country collect information about diverse circumstances; for instance, the degree of indebtedness, liquidity problems, the state of confidence of the entrepreneur, the animal spirits, etc. 
correlated with $y_{i t-1}$ but not with $\alpha_{i}$ - instead of dropping $\alpha_{i}$ with the model in differences. Equation (14) and (15) show the moment conditions considered by this technique

$$
\begin{aligned}
& E\left[\Delta y_{i, t-s}\left(\eta_{i t}+\mu_{i}\right)\right]=0 \\
& E\left[\Delta x_{i, t-s}\left(\eta_{i t}+\mu_{i}\right)\right]=0
\end{aligned}
$$

for $s \geq 2 ; t=1, \ldots, T$

Finally, the results obtained with these two methods are evaluated by applying the following tests: a) the Sargan test (Sargan, 1958; Hansen, 1982) of orthogonality between the instruments and the residuals, which makes it possible to test the validity of the instruments that are used in the regression through a comparison between the estimated moments and the sample moments; ${ }^{13}$ and $b$ ) the Arellano and Bond test (Arellano and Bond, 1991) for first- and second-order serial correlation, which allows us to test the null hypothesis of absence of autocorrelation between the residuals ${ }^{14}$. We may note that the presence of n-order autocorrelation means that the residuals are of a $n^{\text {th }}$ order moving average [MA(n)] sequence, and only those variables that are lagged more than $n$ periods are suitable instruments. Specifically, a MA(n) sequence describes a variable $y_{t}$ as is shown in expression (16):

$$
y_{t}=\mu+\eta_{t}+\psi_{1} \eta_{t-1}+\psi_{2} \eta_{t-2}+\ldots+\psi_{q} \eta_{t-n}
$$

where $\psi_{t}$ are the estimated parameters, $E\left(y_{t}\right)=\mu$ and $\eta_{t}$ is a succession of independently and identically distributed random variables with $E\left(\eta_{t}\right)=0$ and $\operatorname{Var}\left(\eta_{t}\right)=\sigma^{2}$.

Moreover, other statistics are reported. Specifically, the Arellano and Bond test for third, fourth and fifth-order serial correlation (Arellano and Bond, 1991; Roodman, 2009) is applied when the model is estimated by means of system GMM. These tests cannot be applied in the case of the difference GMM, since this method only enables the testing of autocorrelation for those orders, which are below or equal to the included number of the lags of the dependent variable increased by one unit ${ }^{15}$.

STATA/SE 9.2 is the statistical package that we have employed to estimate the econometric regressions of this contribution ${ }^{16}$.

(13) The Sargan test assumes that the instruments are truly exogenous only when the residuals are uncorrelated with the set of exogenous variables.

(14) These techniques, which work in differences, induce first-order autocorrelation in the estimated models.

(15) All the models and statistics, which are shown in the following section, have been estimated by means of the command xtabond2 (Roodman, 2009).

(16) STATA/SE 9.2 (April 2006) by StataCorp. 


\section{Data}

Our theoretical relationship is tested against a panel, which starts in 1970 and ends in 2010; the period chosen is due to the availability of consistent data series. More specifically, we must start with the 1970 data for several reasons: a) the data on dwelling and gross fixed capital formation are only available since 1970 for some of the countries included in our sample; b) there is a lack of homogenous information about financial variables, such as stock market indices before this time. In fact, this lack of availability of data compels us to include only five indices; ${ }^{17}$ and c) the statistics on capacity utilization was first published during the 1960s and the consistent series could only be found since 1970. Our sample includes the following countries: Australia, Austria, Belgium, Canada, Denmark, France, Germany, Italy, Netherlands, Norway, Spain, Sweden, the United Kingdom and the United States.

The majority of the data come from the AMECO databank, where there is available and consistent annual data series for the countries under consideration. AMECO is published by the European Commission's Directorate General for Economic and Financial Affairs and offers annual macroeconomic information on a great number of variables ${ }^{18}$.

The OECD database Business tendency and consumer opinion surveys publishes capacity utilization information. However, the quarterly Australian series are provided by the Australian Chamber of Commerce and Industry (ACCI Westpac Survey of Industrial Trends) and the monthly US data by the Federal Reserve website (G.17 Industrial Production and Capacity Utilization, Capacity utilization: Total Industry). In all of these cases, the annual average capacity utilization is calculated by using four quarterly data, except for the US, where the annual time series is the average value of the twelve observations.

Regarding the financial variables, the main source of data is the Wren Investment Advisers website. This databank provides the annual US Treasury longterm bond yields, the AXS, and the FTSE indices, which cover the whole period. Other sources used are: Deutsche Bundesbank, which publishes annual DAX series; Standard \& Poor's, which has provided daily observations of the Standard

(17) We may note that the development of stock markets is included in our model through the evolution of the DAX index for all the European economies except for the United Kingdom, where FTSE is more relevant, and IGBM for Spain. In the case of the United States and Canada the relevant index is the Standard \& Poor's, and AXS is computed for Australia.

(18) The lack of statistics on business capital stock in this databank compels us to calculate the dependent variable of our model, business accumulation rate, in the following way:

$$
g_{t}=\frac{G F C F_{t}^{p r}-D_{t}}{K_{t-1}}=\frac{I_{t}^{b}}{K_{t-1}}
$$

where $g$ is the business rate of accumulation, $G F C F^{p r}$ is the private gross fixed capital formation in the private sector, $D$ accounts for dwellings, $I^{b}$ is the business investment and $K$ is the capital stock in the total economy. 
\& Poor's index since 1989, with previous monthly data being available on the IESE Business School University of Navarra website. Finally, Bolsa de Madrid has offered daily information on the IGBM index since 2003 and the IESE Business School University of Navarra provides annual observations for the rest of the period under consideration. For those financial variables for which there is no annual information available, we have had to convert the daily or monthly data provided in annual time series by calculating the average value.

\section{Empirical evidence}

We utilise two lags of each variable for estimation purposes, since there are considerable delays in the investment process due to the fact that new investment projects require some time between the investment decision and when the new equipment begins to produce. This time horizon is enough to capture the investment delay, as has been demonstrated by other studies, as for example Bean (1981), where a lag structure of three quarters and a delay of seven quarters is found, and Evans (1967) where five and six quarters lags are empirically established. Moreover, our estimations also include lags of the accumulation rate as an explanatory element. This enables us to account for the inertia of the accumulation process.

All the conventional levels of the included variables are defined by using the Hodrick and Prescott (1980) filter, which allows the construction of businessmen's expectations based on the trends of the variables employed. The Hodrick and Prescott (op. cit.) filter is also applied to the rate of growth of GDP in order to capture the tendency of this particular element in order to define businessmen's expected demand. This is so since new investment projects take place only when increases in demand are permanent, while temporal and unexpected peaks of demand are dealt with by varying capacity utilization. Specifically, this filter isolates the trend and the cyclical components that form a particular time series; and works by minimizing the square of the deviations from the trend and by penalising changes in the acceleration of the trend of the time series.

Table 1 summarises the econometric results. Model I and Model II are estimated by applying the difference GMM. The difference between them is the specification, where Model I includes two lags of each regressor, while Model II drops those variables that do not have a significant coefficient. Moreover, Table 1 presents two regressions estimated by the system GMM: Model III, which shows the unrestricted specification of our investment function; and Model IV, which is chosen by applying the same criteria as in Model II. The criteria, which have been utilised to obtain the restricted specifications that are presented in Model II and IV, are consistent with the 'general-to-specific' modelling approach (Hendry; Richard, 1983). 
Table 1

Econometric results for accumulation Model (1970-2010)

\begin{tabular}{|c|c|c|c|c|}
\hline \multirow{2}{*}{$\begin{array}{l}\text { Equation } \\
\text { Dependent }\end{array}$} & Model I & Model II & Model III & Model IV \\
\hline & $\mathrm{a}$ & $\mathrm{a}$ & $\mathrm{a}$ & $\mathrm{a}$ \\
\hline Constant & -0.0000 & $-0.0001 * *$ & -0.0032 & 0.0097 \\
\hline $\mathrm{g}(1)$ & $1.1100 * * *$ & $1.0870 * * *$ & $1.2114 * * *$ & $1.1784 * * *$ \\
\hline g (2) & $-0.2310 * * *$ & $-0.1974 * *$ & $-0.2720 * *$ & $-0.2436 * * *$ \\
\hline y (1) & $0.4453^{*}$ & & $0.2973 * *$ & $0.0672 * *$ \\
\hline $\mathrm{y}(2)$ & -0.3508 & & $-0.2654 *$ & \\
\hline $\mathrm{du}(1)$ & 0.0005 & & $0.0006^{* * *}$ & $0.0006^{* * *}$ \\
\hline $\mathrm{du}(2)$ & -0.0003 & & -0.0002 & \\
\hline$\pi(1)$ & $0.0836^{* *}$ & $0.0659 * *$ & 0.0643 & $0.0168 * *$ \\
\hline$\pi(2)$ & -0.0165 & & -0.0468 & \\
\hline e (1) & $-0.0847^{*}$ & & $-0.0965^{*}$ & $-0.0173 *$ \\
\hline e (2) & $0.1088 * *$ & & $0.0938 *$ & \\
\hline di (1) & 0.0001 & & 0.0001 & \\
\hline $\operatorname{di}(2)$ & $-0.0001^{*}$ & $-0.0002 * * *$ & $-0.0001 * * *$ & $-0.0002 * * *$ \\
\hline dre (1) & $-0.0171 * * *$ & & $-0.0213 * *$ & \\
\hline dre (2) & -0.0074 & $-0.0166 * *$ & -0.0091 & $-0.0190 * * *$ \\
\hline $\mathrm{dS}(1)$ & $0.0262 * * *$ & & $0.0210 * *$ & \\
\hline $\mathrm{dS}(2)$ & $-0.0361 * * *$ & $-0.0258 * * *$ & $-0.0318 * * *$ & $-0.0320 * * *$ \\
\hline $\mathrm{rb}(1)$ & $-0.0398 *$ & & $-0.0593 * *$ & $-0.0442^{*}$ \\
\hline $\mathrm{rb}(2)$ & 0.0062 & & 0.017 & \\
\hline Method & GMM & GMM & GMM-sys & GMM-sys \\
\hline $\begin{array}{l}\text { Number of observations } \\
\text { (countries) }\end{array}$ & $518(14)$ & $531(14)$ & $518(14)$ & $518(14)$ \\
\hline $\begin{array}{l}\text { Wald test of joint } \\
\text { significance } \\
\text { (p-value) }\end{array}$ & $\begin{array}{l}3848.68 \\
(0.0000)\end{array}$ & $\begin{array}{l}3703.01 \\
(0.0000)\end{array}$ & $\begin{array}{l}6390000000 \\
\quad(0.0000)\end{array}$ & $\begin{array}{l}25325.5 \\
(0.0000)\end{array}$ \\
\hline $\begin{array}{l}\text { 1st-order autocorrelation } \\
\text { (p-value) }\end{array}$ & $\begin{array}{c}-11.94 \\
(0.0000)\end{array}$ & $\begin{array}{l}-11.78 \\
(0.0000)\end{array}$ & $\begin{array}{c}-2.56 \\
(0.0110)\end{array}$ & $\begin{array}{c}-2.56 \\
(0.0110)\end{array}$ \\
\hline $\begin{array}{l}\text { 2st-order autocorrelation } \\
\text { (p-value) }\end{array}$ & $\begin{array}{c}-0.36 \\
(0.7165)\end{array}$ & $\begin{array}{c}-1.28 \\
(0.1994)\end{array}$ & $\begin{array}{c}-0.73 \\
(0.4680)\end{array}$ & $\begin{array}{c}-1.06 \\
(0.2890)\end{array}$ \\
\hline $\begin{array}{l}\text { 3rd-order autocorrelation } \\
\text { (p-value) }\end{array}$ & - & - & $\begin{array}{c}1.48 \\
(0.1390) \\
\end{array}$ & $\begin{array}{c}1.54 \\
(0.1250)\end{array}$ \\
\hline $\begin{array}{l}\text { 4th-order autocorrelation } \\
\text { (p-value) }\end{array}$ & - & - & $\begin{array}{c}-1.09 \\
(0.2740)\end{array}$ & $\begin{array}{c}-1.25 \\
(0.2120)\end{array}$ \\
\hline $\begin{array}{l}\text { 5th-order autocorrelation } \\
\text { (p-value) }\end{array}$ & - & - & $\begin{array}{c}0.12 \\
(0.9040)\end{array}$ & $\begin{array}{c}0.30 \\
(0.7630)\end{array}$ \\
\hline Sargan test (p-value) & $\begin{array}{c}487.37 \\
(1.0000)\end{array}$ & $\begin{array}{c}483.34 \\
(1.0000)\end{array}$ & $\begin{array}{r}502.57 \\
(0.3970) \\
\end{array}$ & $\begin{array}{r}500.35 \\
(0.424) \\
\end{array}$ \\
\hline
\end{tabular}

Note: $* * *, * *$ and $*$ indicate statistical significance and rejection of the null at the 1 , 5 and 10 percent significance levels, respectively. Numbers in parentheses, in the case of the variables, show the lag(s) of the relevant variable. 
The diagnostics/statistics, which validate these econometric results, are reported in the lower part of Table 1. All of the models reported in Table 1 reject the null hypothesis of the Wald test of joint significance. The Wald test checks the value of the regressors by taking into account the sample under consideration, and in the case of Table 1 provides for the acceptance of the estimated parameters. The results of the Sargan test, which are provided in each case, validate the instruments included in the estimated relationships. Finally, the autocorrelation between the residuals is examined, since this would indicate whether we can use lags of the dependent and independent variables as suitable instruments. Those relationships that are estimated by difference GMM (Model I-II), do not display first- and second-order autocorrelation. Nevertheless, Model III and IV, which use the system technique, reject the null hypothesis of absence of first-order autocorrelation; they fulfil, nonetheless, the condition of absence of second- and higher-order autocorrelation. However, the presence of first-order autocorrelation in a system GMM regression is not a problem. In fact, we can expect the presence of this phenomenon since these models are built by applying differences to the initial equation and the lagged variables to produce the equation in differences and the instruments of the equation in levels (Arellano and Bond, 1991). In this sense, the residuals of the equation in differences are those that we need to examine seriously. The results of these tests permit us to validate our estimations, which are described in greater detail as follows.

To begin with the econometric results, the first column (Model I) reports a positive impact of the expected rate of growth of demand (0.4453) and profit shares in $t-1$ (0.0836) on accumulation. This unrestricted specification, which was estimated by difference GMM, also shows how a rise in the cost of external finance in $t-2(-0.0001)$ and the presence of increasing uncertainty $(-0.0171)$ in the previous period dampen current investment. Moreover, an increase in the yield of the US treasury bonds exerts a negative and strong incidence on investment (-0.0398). This is so since this increase makes it more attractive to invest in financial assets without risk, and indirectly, since this increases the cost of external finance. This model also captures a double effect, which comes from the stock market. Specifically, in the shorter horizon $(t-1)$ there is a positive impact $(0.0262)$, which has to be interpreted according to Tobin's $q$ (Brainard and Tobin, 1968, 1977). However, the development of the stock exchange causes a stronger negative effect on accumulation in $t-2(-0.0361)$. A rather contradictory impact of the level of employment is evident in the case of Model I. The labour constraint dampens investment in $t-1$ (-0.0847), although high levels of employment, which are maintained through time can push demand and influence investment positively (0.1088). 
In the restricted version of this model (Model II) the key variable of the model is the profit share (0.0659), which has the expected positive effect. A negative incidence emanates from the stock market $(-0.0258$ in $t-2)$. This version of the model also displays a negative effect of the cost of external finance and the presence of uncertainty $(-0.0002$ and -0.0166 respectively). However, the estimation of the model by means of the system GMM method, which provides more efficient regressors, increases the number of significant variables in the case of the restricted version. Model III, which considers two lags for each independent variable, portrays a positive relationship between the rate of growth of GDP in $t-1$ and investment (0.2973). Another variable, which accelerates capital accumulation, is the deviation of capacity utilization in $t-1$ (0.0006). However, all the financial elements have a negative effect on accumulation. Specifically, increasing interest rates, rising values of the stock markets and higher US Treasury bond yields dampen accumulation by $-0.0001,-0.0318$ and -0.0593 respectively. A positive influence of the stock market on investment is also found (0.0210), which is consistent with the Tobin $q$ model (Brainard and Tobin, 1968, 1977). Model III also shows a double and conflicting impact of the labour market: first, the labour constraint, which depresses accumulation $(-0.0965)$ is present in $t-1$; second, there is a positive impact (0.0938) that arises from the level of employment in $t-2$. A high level of employment favours good expectations about future demand. Finally, and as expected, the model shows an inverse relationship between uncertainty and accumulation (-0.0213).

The last column displays the preferred estimation, since the independent variables are significant, have the correct signs and the model satisfies the basic statistical requirements reported in Table 1. Model IV exhibits a positive impact of expectations about future demand (0.0672), profit shares (0.0168) and deviation of capacity utilization on accumulation (0.0006). However, this model provides the labour constraint with a role, which depresses investment according to the theoretical hypothesis (-0.0173). This specification also reports a depressive effect of interest rates $(-0.0002)$ and bonds $(-0.0442)$. As the theory suggests, uncertainty depresses new investment (-0.0196). Deviations of the stock market index exert a remarkable negative effect $(-0.0380)$, which reinforces our hypothesis that the development of the stock market crowds out physical investment. We may note that all these variables are lagged once, except for the deviation of the exchange rate, interest rate and the stock market, which are lagged in two periods.

The econometric analysis undertaken supports the theoretical premise, as elaborated in section 3. This study reinforces the idea that the core of the investment decision is the accelerator term. As the theoretical framework of the paper suggests, there are two other elements that accelerate the process of capital accumulation: profit shares and deviations of capacity utilization. However, 
entrepreneurs' expectations about future demand exert the strongest positive impact on accumulation, since a weak effective demand does not encourage businessmen to increase capacity even when internal finance is available. The incidence of profit shares is relevant, although the intensity of this effect is lower than the one that emerges from expectations about demand. In terms of capacity utilization, its influence is not very strong, since it would only have an impact when the gap between effective capacity utilization and its normal level is too big and maintained over a long period. It requires that demand is systematically stronger than expected for new investment projects to be undertaken. The negative effect of the labour market conditions is not the most important. A negative effect on the rate of interest may be expected and is thus reported.

The econometric results reported in Table 1 produce an inverse effect of uncertainty, as suggested by our theoretical framework. Its incidence is remarkable since the proxy of uncertainty employed, the exchange rate, can affect accumulation through different channels, i.e. international and monetary markets. A negative and strong influence of the stock market on accumulation is also reported. This reinforces the idea of the presence of a kind of crowding-out between financial and physical investment, which takes place in a financialised economy.

Finally, our study takes into account the US Treasury long-term bond yield as a way of including the effect of a 'safe heaven'. The depressive effect of this financial variable is high since an increase in these yields is directly related to the opportunity to obtain profits without risk; and indirectly in that a rise in the cost of external finance reduces the possibility of profiting from a new project financed externally.

\section{Concluding remarks}

The purpose of this paper is to analyse the accumulation path in capitalist economies, where financial markets have become one of the fundamental pillars of the system, especially so after the financialisation process, which began in the early 1970s. Although our contribution is rooted in the basic Keynesian model, it is extended to account for the possibility of external finance (interest rates) and two financial alternatives in terms of investing in physical assets: bonds and equities. The former is introduced through the US Treasury long-term bond yield and the latter through the stock market. The inclusion of financial markets, which fits in well with the presence of uncertainty, compels us to consider a proxy for this variable. The exchange rate is used for this purpose.

In our theoretical framework, entrepreneurs' expectations are built according to the Keynesian notion of conventions, which helps to take the 
investment decision in a world dominated by radical uncertainty. The idea of a conventional or normal level is also applied to the variable, which proxies the level of economic activity, i.e. capacity utilization, and permits the creation of a deviation between the effective level and the conventional one. Specifically, deviations of capacity utilization are justified on the premise that businessmen cannot precisely predict expected demand and they decide to maintain idle capacity in normal conditions. Moreover, the level of employment is considered as another indicator of the level of economic activity, whose impact highlights the presence of labour constraints in the process of accumulation and the existence of tensions between workers and firms, which could depress business investment.

Our particular approach is tested econometrically by means of the difference GMM and the system GMM techniques with a panel, which collects annual information about 14 OECD countries from 1970 till 2010. The empirical analysis points to the accelerator term as the main explanatory element, which exerts the strongest positive effect on investment. Accumulation is also affected by the presence of equities and the impact of deviations between capacity utilization and its normal level. Nevertheless, there is an inverse relationship between financial elements (the US Treasury bonds and stock markets) and capital accumulation, what reinforces the hypothesis of a conflict between physical and financial investment. Our model also highlights a negative incidence of uncertainty on accumulation, since this phenomenon makes it more difficult for businessmen to foresee the future. Finally, this study emphasises how changes in interest rates can affect investment. The estimated relationships confirm the theoretical explanation of the accumulation process as presented in section 3 .

\section{References}

ALONSO-BORREGO, C.; ARELLANO, M. Symmetrically normalised instrumental-variable estimation using panel data. Journal of Business and Economic Statistics, v. 17, n. 1, p. 36-49, 1996.

AMADEO, E. The role of capacity utilization in long-period analysis. Political Economy, v. 2, p. 147-85, 1986.

ARELlANO, M.; BOND, S. Some tests of specification for panel data: Monte Carlo evidence and an application to employment equations. Review of Economic Studies, v. 58, n. 2, p. 277-297, 1991.

ARELLANO, M.; BOVER, O. Another look at the instrumental variable estimation of error-components models. Journal of Econometrics, v. 68, n. 1, p. 29-51, 1995. 
ARESTIS, P. New consensus macroeconomics and Keynesian critique. In: HEIN, E.; NIECHOJ, T.; STOCKHAMMER, E. (Ed.). Macroeconomic policies on Shaky Foundations: wither mainstream macroeconomics? Marburg: Metropolis, 2009.

ARESTIS, P.; SAWYER, M. How many cheers for the Tobin financial transaction tax. Cambridge Journal of Economics, v. 21, n. 6, p. 753-768, 1997.

BADDELEY, M. Keynes on rationality, expectations and investment. In: SARDONI, C. (Ed.). Keynes, post Keynesianism and political economy: essays in honour of Geoff Harcourt. London: Routledge, 1999. v. III.

BALTAGI, B. H. Econometric analysis of panel data. Chichester: Whiley, 1995.

BAltaGi, B. H. Panel data models. In: MILlS, T. E.; PATTERSON, K. (Ed.). Palgrave handbook of econometrics. New York: Palgrave Macmillan, 2006. v. I.

BEAN, C. R. An econometric model of manufacturing investment in the UK. Econometric Journal, v. 91, p. 106-121, 1981.

BHADURI, A.; MARGLIN S. Unemployment and the real wage: the economic basis for contesting political ideologies. Cambridge Journal of Economics, v. 14, n. 4, p. 375-393, 1990.

BRAINARD, W. C.; TOBIN, J. Pitfalls in financial model building. American Economic Review, v. 58, n. 2, p. 99-122, 1968.

BRAINARD, W. C.; TOBIN, J. Asset markets and the cost of capital. In: BELASSA, B.; NELSON, R. (Ed.). Economic progress, private values and public policy: essays in honour of William Fellner. New York: North-Holland, 1977. v. I.

BRONDOLO, J. Taxing financial transactions: an assessment of administrative feasibility. Washington, D.C.: International Monetary Fund, 2011. (IMF Working Paper, WP/11/185).

DALLERY, T.; van TREECK, T. Conflicting claims and equilibrium adjustment processes in a stock-flow consistent macroeconomic model. Review of Political Economy, v. 23, n. 2, p. 189-211, 2011.

DAVIDSON, P. Is probability theory relevant for uncertainty? A post Keynesian perspective. Journal of Economic Perspectives, 5 (1): 19-43. 1991

DiNARDO, J.; MOORE, M. P. The Phillips Curve is back? Using panel data to analyze the relationship between unemployment and inflation in an open economy. Cambridge, MA: National Bureau of Economic Research, 1999. (NBER Working Paper, n. 7328).

DUTT, A. K. Stagnation, income distribution and monopoly power. Cambridge Journal of Economics, v. 8, n. 1, p. 25-40, 1984. 
DUTT, A. K. Equilibrium, path dependence and hysteresis in post-Keynesian models. In: ARESTIS, P.; PALMA, G.; SAWYER, M. (Ed.). Capital controversy, post-Keynesian economics and the history of economic thought: essays in honour of Geoff Harcourt. London: Routledge, 1997.

DUTT, A. K. Growth and income distribution: a post-Keynesian perspective. In: HEIN, E.; STOCKHAMMER, E. (Ed.). A modern guide to Keynesian macroeconomics and economic policies. Cheltenham: Edward Elgar, 2011.

FUNDACIÓN IDEAS. Impuestos para frenar la especulación financiera. Madrid, May 2010. (Report).

EVANS, M. K. A study of industry investment decisions. Review of Economic Statistics, v. 53, n. 1, p. 151-164, 1967.

HANSEN, L. P. Large sample properties of generalised method of moments estimators. Econometrica, v. 50, n. 4, p. 1029-1054, 1982.

HEIN, E.; OCHSEN, C. Regimes of interest rates, income equities, savings and investment: a Kaleckian model and empirical estimations for some advanced OECD economies. Metroeconomica, v. 54, n. 4, p. 404-433, 2003.

HEIN, E. Interest, debt, distribution and capital accumulation in a post-Kaleckian model. Metroeconomica, v. 58, n. 2, p. 310-339, 2007.

HENDRY, D.; RICHARD, J. The econometric analysis of economic time series. International Statistics Review, v. 51, n. 2, p. 3-33, 1983.

HODRICK, R. J.; PRESCOTT E. C. Postwar US business cycles: an empirical investigation. Carnegie-Mellon University, 1980. (Manuscript).

HSIAO, C.; MOUNTAIN, D. C. A framework for regional modelling and impact analysis: an analysis of the demand for electricity by large municipalities in Ontario, Canada. Journal of Regional Science, v. 34, n. 3, p. 361-385, 1994.

IMF. World Economic Outlook Database. General government gross debt. Percent of GDP. Washington, D. C.: International Monetary Fund, 2010.

KEYNES, J. M. The general theory of employment, interest and money. London: Macmillan, 1936.

LAVOIE, M. Interest rates in post-Keynesian models of growth and distribution. Metroeconomica, v. 46, n. 2, p. 146-177, 1995.

LAVOIE, M.; RODRÍGUEZ, G.; SECCARECCIA, M. Similitudes and discrepancies in post-Keynesian and Marxist theories of investment: a theoretical and empirical investigation. International Review of Applied Economics, v. 18, n. 2, p. 127-149, 2004. 
LAYARD, R.; NICKELL, S. J. Unemployment in Britain. Economica, v. 53, p. 121-129, 1986.

LAYARD, R.; NICKELL, S. J.; JACKMAN, R. Unemployment: macroeconomic performance and the labour market. Oxford: Oxford University Press, 1991.

NICKELL, S.; NUNZIATA, L. Unemployment in the OECD since the 1960s. What do we know? Paper presented at the Conference entitled Unemployment. London: London School of Economics, 2002.

OECD. Revenue statistics, 1965-2010. Paris: OECD Publishing, 2011.

RADCLIFFE REPORT. Report of the Committee on the Working of the Monetary System. London: Her Majesty's Stationary Office, Cmd 827, 1957.

ROODMAN, D. How to do xtabond2: an introduction to 'difference' and 'system' GMM in stata. Stata Journal, v. 9, n. 1, p. 86-136, 2009.

RYOO, S.; SKOTT, P. Financialization in Kaleckian economies with and without labor constraints. Intervention. European Journal of Economics and Economic Policies, v. 5, n. 2, p. 357-386, 2008.

SARGAN, J. The estimation of economic relationships using instrumental variables. Econometrica, v. 26, n. 3, p. 393-415, 1958.

SKOTT, P. Effective demand, class struggle and cyclical growth. International Economic Review, v. 30, p. 231-247, 1989.

SKOTT, P.; ZIPPERER, B. An empirical evaluation of three post Keynesian models. University of Massachusetts, 2010. (Working Paper, 2010-08).

STOCKHAMMER, E. Financialisation and the slowdown of accumulation. Cambridge Journal of Economics, v. 28, n. 5, p. 719-741, 2004a.

STOCKHAMMER, E. The rise of unemployment in Europe. Cheltenham: Edward Elgar, 2004b.

STOCKHAMMER, E.; GRAFL, L. Financial uncertainty and business investment. Review of Political Economy, v. 22, n. 4, p. 551-568, 2010.

TOBIN, J. A proposal for international monetary reform. Eastern Economic Journal, v. 4, p. 153-159, 1978. 